\section{Improving Nitrogen and Phosphorus Fertilizer Use Efficiency for Florida's Horticultural Crops}

\author{
Thomas A. Obreza ${ }^{1}$ and Jerry B. Sartain
}

\begin{abstract}
AdDITIONAL INDEX WORDs. nutrients, best management practice, fertigation
Summary. Florida's citrus (Citrus spp.), vegetable, and turfgrass industries must improve nitrogen $(\mathrm{N})$ and phosphorus $(\mathrm{P})$ fertilizer use efficiency to remain sustainable in an era of emerging environmental policies designed to protect water quality. Producers have traditionally used water-soluble $\mathbf{N}$ and $\mathbf{P}$ fertilizers because they are plentiful and economical. Improving nutrient use efficiency (NUE) is being addressed through implementation of best management practices (BMPs) such as nutrient management planning, proper fertilizer material selection, better application timing and placement, and improved irrigation scheduling. Emerging technology that will aid in this effort includes increased use of enhanced efficiency fertilizers (EEFs), organic soil amendments, fertigation, and foliar fertilization. However, any new technology shown to improve NUE must be economically feasible before it can be considered a BMP. Future research in this area will aim to improve the economics of EEFs and precision fertilizer application.
\end{abstract}

$\mathrm{F}$ lorida's citrus, vegetable, ornamental, and turf growers walk a fine line as they attempt to maintain economical production while simultaneously protecting the surrounding environment from excessive nutrients. In the face of increased fertilizer cost and stringent environmental regulation, these industries have a critical need to improve nitrogen $(\mathrm{N})$ and phosphorous (P) fertilizer use efficiency to remain sustainable. Plant nutrient management is intensive when producing high-value horticultural crops that demand high fertilizer and irrigation inputs. Producers cannot afford a decrease in crop volume or quality due to nutrient deficiency, especially considering the total capital outlay required to produce a crop [e.g., more than $\$ 25,000 /$ ha for tomato (Solanum lycopersicum) production]. When applied nutrients are not taken up by the crop, fertilization efficiency decreases and unused $\mathrm{N}$ and $\mathrm{P}$ can be lost through leaching or runoff to groundwater or surface water. Total maximum daily load (TMDL) implementation in Florida will limit $\mathrm{N}$ and/or $\mathrm{P}$ loading in watersheds where horticultural crops are grown. If nutrient management practices within a watershed are not efficient enough to meet prescribed TMDLs, then the industry could face penalties

Soil and Water Science Department, University of Florida, P.O. Box 110290, Gainesville, FL 32611

${ }^{1}$ Corresponding author. E-mail: obreza@ufl.edu. that would threaten its viability in that watershed.

The objective of this article is to describe general avenues and new directions that Florida's horticultural crop producers can take to improve $\mathrm{N}$ and $\mathrm{P}$ nutrient use efficiency (NUE), defined as the ratio of the amount of fertilizer nutrient taken up by the target plant to the amount applied. First, common water-soluble fertilizer (WSF) materials that have been used for decades to supply $\mathrm{N}$ and $\mathrm{P}$ to horticultural crops are characterized, and best management practices (BMPs) that are being implemented to minimize off-site nutrient loss are summarized. Second, alternative fertilizer sources and methods of application that have been shown to improve NUE are explored. Finally, high-priority research topics that will improve our knowledge about how to keep nutrients in the horticultural crop root zone are suggested.

\section{Water-soluble $\mathbf{N}$ and $\mathbf{P}$ fertilizers}

Water-soluble fertilizers dominate in Florida because they are plentiful and cost considerably less than slow or controlled-release fertilizers. A negative aspect about water-soluble $\mathrm{N}$ fertilizer is that it readily and rapidly leaches through Florida's sandy soils with excessive rainfall or irrigation. Five materials make up essentially the entire suite of water-soluble $\mathrm{N}$ fertilizers used (Table $\mathrm{l}$ ). Each material has unique characteristics that make it suitable or unsuitable for particular horticultural applications (Sartain and Kruse, 2001). For example, the acidifying property of ammonium sulfate makes it desirable for application to acid-loving plants such as highbush blueberry (Vaccinium corymbosum). On the other hand, urea is not suitable for application to Florida's alkaline soils due to ammonia volatilization hazard.

Phosphorus fertilizers applied in Florida are almost entirely water-soluble materials. An exception occurs when a polymer-coated $\mathrm{N}-\mathrm{P}-\mathrm{K}$ material is used that applies a small amount of $\mathrm{P}$ in controlled-release form. The group of water-soluble $\mathrm{P}$ fertilizers used in Florida is comprised of four materials that each have unique characteristics (Table 2). They are quite versatile in their horticultural application, but there are a few instances where a particular material should not be used (Sartain and Kruse, 2001). For example, diammonium phosphate should not be applied to an alkaline soil due to volatilization of $\mathrm{N}$ and loss of $\mathrm{P}$ availability.

The efficiency of WSFs can be enhanced by using appropriate rates, sources, application timing, and placement.

\begin{tabular}{llll}
\hline $\begin{array}{l}\text { Units } \\
\text { To convert U.S. to SI, } \\
\text { multiply by }\end{array}$ & U.S. unit & SI unit & $\begin{array}{l}\text { To convert SI to U.S., } \\
\text { multiply by }\end{array}$ \\
\hline 0.4047 & $\mathrm{acre}(\mathrm{s})$ & $\mathrm{ha}$ & 2.4711 \\
0.3048 & $\mathrm{ft}$ & $\mathrm{m}$ & 3.2808 \\
2.54 & $\mathrm{inch}(\mathrm{es})$ & $\mathrm{cm}$ & 0.3937 \\
0.4536 & $\mathrm{lb}$ & $\mathrm{kg}$ & 2.2046 \\
48.8243 & $\mathrm{lb} / 1000 \mathrm{ft}^{2}$ & $\mathrm{~kg} \cdot \mathrm{ha}^{-1}$ & 0.0205 \\
1.1209 & $\mathrm{lb} / \mathrm{acre}$ & $\mathrm{kg} \cdot \mathrm{ha}^{-1}$ & 0.8922 \\
28.3495 & $\mathrm{oz}$ & $\mathrm{g}$ & 0.0353 \\
0.001 & $\mathrm{ppm}$ & $\mathrm{g} \cdot \mathrm{L}^{-1}$ & 1000 \\
1 & $\mathrm{ppm}$ & $\mathrm{mg} \cdot \mathrm{L}^{-1}$ & 1 \\
2.3385 & $\mathrm{qt} / \mathrm{acre}$ & $\mathrm{L} \cdot \mathrm{ha}^{-1}$ & 0.4276 \\
2.2417 & ton/acre & $\mathrm{t} \cdot \mathrm{ha}^{-1}$ & 0.4461 \\
$\left({ }^{\circ} \mathrm{F}-32\right) \div 1.8$ & ${ }^{\circ} \mathrm{F}$ & ${ }^{\circ} \mathrm{C}$ & $\left(1.8 \times{ }^{\circ} \mathrm{C}\right)+32$
\end{tabular}

Hortlechnology · February $201020(1)$ 
Table 1. Properties of water-soluble nitrogen $(\mathrm{N})$ fertilizers used in Florida commercial horticulture production.

\begin{tabular}{|c|c|c|c|c|c|}
\hline Property & $\begin{array}{l}\text { Ammonium } \\
\text { sulfate }\end{array}$ & $\begin{array}{c}\text { Ammonium } \\
\text { nitrate }\end{array}$ & Urea & $\begin{array}{c}\text { Potassium } \\
\text { nitrate }\end{array}$ & $\begin{array}{c}\text { Calcium } \\
\text { nitrate }\end{array}$ \\
\hline Water solubility $\left(\mathrm{g} \cdot \mathrm{L}^{-1}\right)^{\mathrm{z}}$ & Moderate (708) & High (1175) & High (780) & Moderate (132) & High $(1211$ \\
\hline Ammonia volatilization potential & $\operatorname{High}^{\mathrm{y}}$ & Moderate & $\operatorname{High}^{x}$ & None & None \\
\hline $\begin{array}{l}\text { Calcium carbonate equivalent } \\
{[\text { per unit }(20 \mathrm{lb}) \text { of } \mathrm{N}]^{\mathrm{z}}}\end{array}$ & -5.35 & -1.80 & -1.80 & +1.80 & +1.20 \\
\hline Salt index [per unit $(20 \mathrm{lb})^{\mathrm{w}}$ of $\mathrm{N}$ ] & 3.25 & 3.06 & 1.62 & 5.34 & 4.19 \\
\hline Citrus & $\mathrm{X}$ & $\mathrm{X}$ & & & $\mathrm{X}$ \\
\hline Vegetables & $\mathrm{X}$ & $\mathrm{X}$ & & $\mathrm{X}$ & $\mathrm{X}$ \\
\hline Landscape & $\mathrm{X}$ & $\mathrm{X}$ & $\mathrm{X}$ & & \\
\hline Nursery & $\mathrm{X}$ & $\mathrm{X}$ & & & $\mathrm{X}$ \\
\hline Greenhouse & $\mathrm{X}$ & $\mathrm{X}$ & & & $\mathrm{X}$ \\
\hline Deciduous/tropical fruit & $\mathrm{X}$ & $\mathrm{X}$ & & & \\
\hline
\end{tabular}

Table 2. Properties of water-soluble phosphorus $(P)$ fertilizers used in Florida commercial horticulture production.

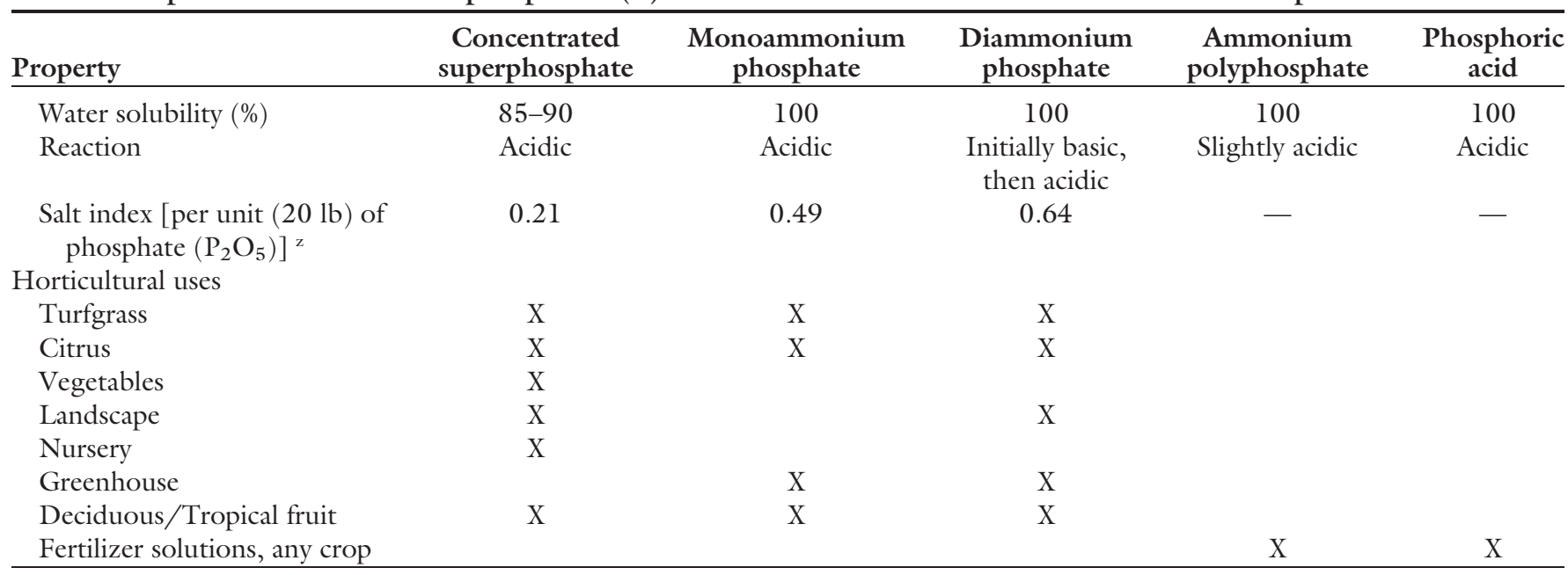

${ }^{2} 20 \mathrm{lb}=9.1 \mathrm{~kg}$.

Specific techniques to improve WSF efficiency in Florida's horticultural production systems are discussed in production guides (Obreza and Morgan, 2008; Olson and Simonne, 2007), and review articles (Hochmuth, 2003; Locascio, 2005), thus they will not be discussed in detail here.

\section{BMPs to improve WSF use efficiency}

In Florida, BMPs are defined as "practices based on research, fieldtesting, and expert review determined to be the most effective and practicable on-location means, including economic and technological considerations, for improving water quality in agricultural and urban discharges." The formal procedure used to estab- lish horticultural crop BMPs after the need was identified included: 1 ) forming a steering committee and technical work groups, 2) producing a draft BMP manual, 3) peer-review and revision, 4) holding public workshops, and 5) adopting the manual in state code. Producers who voluntarily implement BMPs receive a presumption of compliance with water quality standards and are eligible for cost-share funds to improve operations.

Florida Department of Agriculture and Consumer Services (FDACS) has published BMP manuals for sod, container nursery, vegetable, and citrus production (FDACS, 2000, 2002, 2004, 2005, 2006, 2007a, 2007b), while the Florida Department of Environmental Protection (FDEP) has produced BMP manuals for golf courses and turf/ornamental landscapes (Thomas, 2007, 2008). Most nutrient BMPs are simple, commonsense, "good housekeeping" practices. In abbreviated form, they involve: 1) educating and training field operators about how to manage fertilizer, 2 ) developing a nutrient management plan, 3) using appropriate fertilizer sources and formulations, 4) using application equipment that applies fertilizer to target sites, 5) properly calibrating and maintaining application equipment, 6) using precision nutrient application where appropriate, 7) avoiding high-risk fertilizer applications (such as during the rainy season), 8) splitting fertilizer applications throughout the growing season, 9) adding organic matter to the soil whenever possible, and 
10) using soil moisture sensors to improve irrigation scheduling.

\section{Enhanced efficiency fertilizers (EEFs)}

The American Association of Plant Food Control Officials describes EEFs as fertilizer products with characteristics that minimize the potential of nutrient losses to the environment, as compared with "reference soluble" products (Hall, 2006). Enhanced efficiency fertilizers include slow and controlled-release materials as well as nitrification and urease inhibitors. Agronomic effectiveness of EEFs is not implied in this definition, but it is assumed. In Florida, high-volume use of EEFs in horticultural applications is limited to turfgrass, greenhouse, nursery, and landscape settings due to higher costs compared with WSF. Smaller amounts of EEFs are used in citrus replant situations and other specialty horticulture. For example, vegetable growers sometimes include slow-release $\mathrm{N}$ in fertilizer blends applied under plastic mulch.
Nutrient ReleAse from EEFs. There are several modes by which nutrients are released from EEFs (Table 3). Coated fertilizers contain water-soluble $\mathrm{N}$ (alone or in combination with other nutrients) surrounded by an impermeable or semipermeable coating. Nutrients are released by diffusion through the coating or following degradation of the coating. Examples include sulfurcoated urea (SCU), Osmocote ${ }^{\circledR}$ (Scotts, Marysville, OH), Nutricote ${ }^{\circledR}$ (Florikan, Sarasota, FL), and Polyon ${ }^{\circledR}$ (Agrium Advanced Technologies,

Table 3. Properties of enhanced efficiency fertilizers used in Florida commercial horticultural production.

\begin{tabular}{|c|c|c|}
\hline Product & Nutrients & Properties \\
\hline \multicolumn{3}{|l|}{ Synthetic organic compounds } \\
\hline $\begin{array}{l}\text { Ureaformaldehyde reaction } \\
\text { products (UF) }[\text { e.g., } \\
\text { methylene urea }(\mathrm{MU})]\end{array}$ & $38 \%-40 \%$ nitrogen $(\mathrm{N})$ & $\begin{array}{l}\text { Low-solubility organic compound; biological } \\
\mathrm{N} \text { release influenced by soil temperature, } \mathrm{pH} \\
\text { and moisture; roughly a } 90-\mathrm{d} \text { release period } \\
\text { in Florida. }\end{array}$ \\
\hline Isobutylidene diurea (IBDU) & $31 \% \mathrm{~N}$ & $\begin{array}{l}\text { N released by chemical hydrolysis to urea; } \\
\text { release relatively unaffected by temperature; } \\
\text { good cool season response; release is affected } \\
\text { by particle size (smaller = faster); roughly } \\
\text { a } 60 \text {-d release period in Florida. }\end{array}$ \\
\hline \multicolumn{3}{|l|}{ Coated materials } \\
\hline Sulfur-coated urea (SCU) & $32 \%-38 \% \mathrm{~N}$ & $\begin{array}{l}\text { N release depends on thickness of sulfur }(S) \\
\text { coating, biological activity, temperature, and } \\
\text { soil pH; cool season response is erratic; } \\
\mathrm{S} \text { coating can be fragile, and if it cracks, the } \\
\text { slow-release property is lost; roughly a } 60 \text {-d } \\
\text { release period in Florida. }\end{array}$ \\
\hline $\begin{array}{l}\text { Polymer/sulfur-coated } \\
\text { fertilizers (PCU, PCSCU) }\end{array}$ & $41 \%-43 \% \mathrm{~N}$ & $\begin{array}{l}\text { Primary coating of } S \text { with a secondary polymer } \\
\text { coat; use of } S \text { as a coating material decreases } \\
\text { cost of production; coating is abrasion resistant; } \\
\text { nutrients are released by a combination of } \\
\text { diffusion and capillary action; release is less } \\
\text { temperature sensitive than straight } \\
\text { polymer-coated fertilizers. }\end{array}$ \\
\hline $\begin{array}{l}\text { Polyon }{ }^{\circledR} \text { (Agrium Advanced } \\
\text { Technologies, Sylacauga, AL) }\end{array}$ & $41 \%-44 \% \mathrm{~N}$ & $\begin{array}{l}\text { Polyurethane-coated urea; } \mathrm{N} \text { is released by } \\
\text { osmotic diffusion; release rate is influenced } \\
\text { by coating thickness and temperature; } \\
\text { coating is abrasion-resistant. }\end{array}$ \\
\hline $\begin{array}{l}\text { Nutricote }{ }^{\circledR} \text { (Florikan, } \\
\text { Sarasota, FL) }\end{array}$ & $\begin{array}{l}\text { Various concentrations } \\
\text { of } \mathrm{N}, \mathrm{P} \text {, and } \mathrm{K} \text {, plus } \\
\text { secondary and } \\
\text { micronutrients }\end{array}$ & $\begin{array}{l}\text { Soluble fertilizer coated with polyolefin; nutrient } \\
\text { release is controlled by coating composition, not } \\
\text { thickness; continuous moisture is necessary for } \\
\text { nutrient release; release period varies from } 40 \text { to } \\
540 \mathrm{~d} \text {, depending on coating properties. }\end{array}$ \\
\hline
\end{tabular}


Sylacauga, AL). Noncoated EEFs include materials of limited water solubility that release plant-available $\mathrm{N}$ as they decompose chemically or microbially. Examples include ureaformaldehyde (UF), methylene urea (MU), and isobutylidene diurea (IBDU). In all cases, moisture and temperature play a significant role in determining how quickly $\mathrm{N}$ and other nutrients are released.

It is important for a producer to understand how a particular EEF works and to know its designed release rate before applying it in a horticultural situation. Studies evaluating EEF use in vegetable production have emphasized how a crop can suffer if nutrient release is not fast enough (Csizinszky et al., 1993; Graetz et al., 1987). Simonne and Hutchinson (2005) measured $\mathrm{N}$ release rates of 18 EEFs tested for utility in growing potato (Solanum tuberosum). Only three materials released $\mathrm{N}$ at a rate fast enough for potato production; the rest of the materials were too slow. Figure 1 shows an example of an EEF release curve that is wellmatched to plant needs (Medina et al., 2008). Citriblen ${ }^{\circledR}$ fertilizer (Scotts) is formulated for use in mature citrus groves, where recommendations suggest that two-thirds of the $\mathrm{N}$ should be released within 110 $\mathrm{d}$ after applying in the spring.

Timing of EEF application. The goal in EEF application timing is to match the release curve with crop nutrient demand during the growing season (Schwab and Murdock, 2005). For example, newly planted citrus trees should be fertilized at planting, while established trees should receive EEF in late winter or early spring before the first spring vegetative flush and bloom. Turf and ornamental landscapes in southern Florida can receive EEF between April and September, but in northern Florida, it should only be applied between May and July (Sartain, 2007). Vegetables should be fertilized with EEFs preplant, beneath the plastic mulch if applicable (Simonne and Hochmuth, 2007). For greenhouse and nursery crops, EEFs are typically incorporated into the potting media or topdressed after planting.

Placement of EEF. Placement (e.g., surface vs. incorporated) is important to improve NUE and decrease leaching. In an EEF placement study, Broschat (2005) measured lower $\mathrm{N}, \mathrm{P}$, and $\mathrm{K}$ release rates from surface-applied Osmocote ${ }^{\circledR}$ and Nutricote ${ }^{\circledR}$ fertilizers compared with placing them $10 \mathrm{~cm}$ deep in the potting substrate. Million et al. (2007a) found that surface application of Osmocote ${ }^{\circledR}$ to sweet viburnum (Viburnum odoratissimum) did not affect plant growth compared with incorporation, but $\mathrm{N}$ and $\mathrm{P}$ leaching losses were reduced 16\% and $25 \%$, respectively, when the EEF was surface-applied. In a field study, EEFs undergoing evaluation for long-term use on sweet orange (Citrus sinensis) trees were applied to the soil surface even if the manufacturer's instructions stated that the material should be incorporated (Obreza et al., 1999). In all cases, surface application did not detrimentally affect EEF performance, likely because

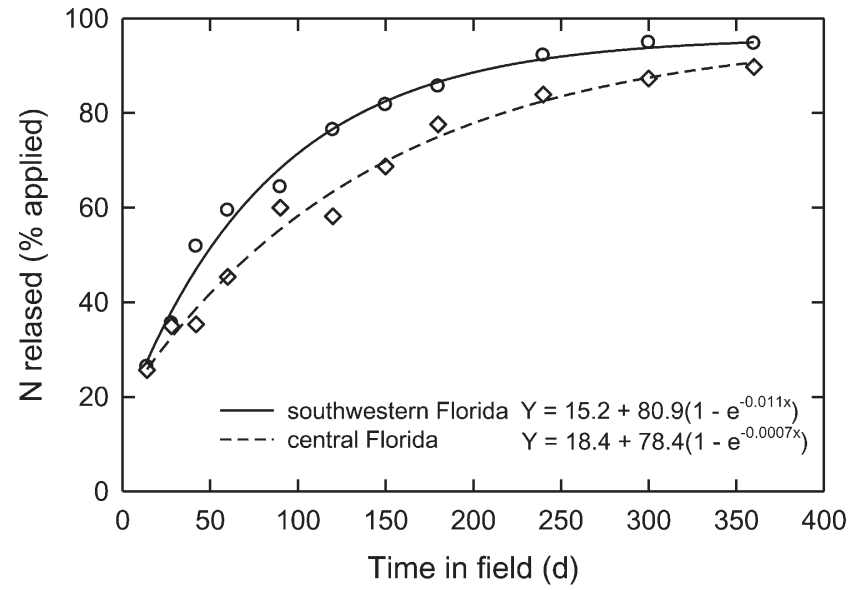

Fig. 1. Nitrogen $(\mathrm{N})$ release patterns of Citriblen ${ }^{\circledR}($ Scotts, Marysville, $\mathbf{O H})$ enhanced efficiency fertilizer measured in southwestern and central Florida (Medina et al., 2008).

it was applied within the wetted pattern of the microirrigation system that maintained a continuous moist environment on the grove floor.

Temperature and moisture EFFECTS ON EEF. Temperature and moisture can affect EEF release rate (Sartain and Kruse, 2001). In most cases, as temperature increases, nutrient release from an EEF increases. However, the temperature-release curve relationship has not been well defined in a quantitative way for many of the EEFs used in Florida. Surfaceapplied EEFs release nutrients more slowly than incorporated EEFs due to intermittent wetting and drying. For continuous nutrient release, EEF particles need to be continuously moist, but they do not require complete water immersion.

Horticultural performance AND N LEACHING. Numerous Florida studies have measured horticultural performance, and in some cases, leaching, of EEFs. Turfgrass has been the most studied crop in the past two decades. In a series of field experiments, polymer-coated ammonium sulfate and polymer-coated urea applied to bermudagrass (Cynodon dactylon), perennial ryegrass (Lolium perenne), and/or st. augustinegrass (Stenotaphrum secundatum) produced equal or better turf growth and quality ratings when compared with a standard fertilization program using WSF (Sartain, 1994c, 1995a; Varshovi and Sartain, 1993, 1996a, 1996b, 1996c). In addition, EEFs reduced $\mathrm{N}$ leaching losses by $50 \%$ to $75 \%$ compared with WSF (Sartain, 1992; Varshovi and Sartain, 1993). However, EEFs have not always performed better than WSF. In a large pot study, Saha et al. (2007) found that even though less $\mathrm{N}$ leaching occurred when st. augustinegrass was fertilized with EEF, higher plant quality was observed where WSF was used.

A typical question that a producer considering the use of EEF asks is: "Can I apply a lower fertilizer rate when using an EEF compared with a conventional WSF program and get the same response?" Environmentally enhanced fertilizer evaluation studies have been structured to answer this question by determining the rate by source interaction in full factorial experiments, but a conglomeration of results (Table 4) suggests there is 
Table 4. Summary of Florida studies comparing enhanced efficiency fertilizers (EEFs) with water-soluble fertilizer (WSF) where it was possible to determine a rate by source interaction from a full factorial experiment.

\begin{tabular}{|c|c|c|c|}
\hline Study reference & Crop & EEFs tested vs. WSF ${ }^{z}$ & $\begin{array}{l}\text { Did a lower rate of EEF } \\
\text { perform as well or better } \\
\text { than a higher rate of WSF? }\end{array}$ \\
\hline Zekri and Koo, 1992 & $\begin{array}{l}\text { Non-bearing } \\
\text { citrus trees }\end{array}$ & $\begin{array}{l}\text { MU, SCU, IBDU, Osmocote }{ }^{\circledR} \\
\quad(\text { Scotts, Marysville, } \mathrm{OH})\end{array}$ & $\begin{array}{l}\text { Yes. In a } 2 \text {-year period, EEFs applied at a } 50 \% \\
\text { rate performed equally well compared with } \\
\text { WSF applied at the recommended }(100 \%) \text { rate. }\end{array}$ \\
\hline $\begin{array}{l}\text { Locascio and } \\
\text { Alligood, } 1992\end{array}$ & Bell pepper & $\begin{array}{l}\text { MU, IBDU, Multicote }{ }^{\circledR} \text { (Haifa } \\
\text { Chemicals, Haifa, Israel), } \\
\text { Nutricote }{ }^{\circledR} \text { (Florikan, } \\
\text { Sarasota, FL) }\end{array}$ & $\begin{array}{l}\text { No. In a single-year study, there was no } \\
\text { interaction between fertilizer source and } \\
\text { rate with respect to pepper yield. }\end{array}$ \\
\hline Sartain, 1993 & $\begin{array}{l}\text { Bermudagrass, } \\
\text { ryegrass }\end{array}$ & IBDU, coated WSF & $\begin{array}{l}\text { In a single-season study, no for turf growth, yes } \\
\text { for turf visual quality; same visual quality from } \\
\text { half-rate of EEF compared with full rate of WSF. }\end{array}$ \\
\hline Csizinszky et al., 1993 & Tomato & PCU & $\begin{array}{l}\text { No. In a single-year study, the EEF was less } \\
\text { effective than WSF. }\end{array}$ \\
\hline Alva and Tucker, 1993 & $\begin{array}{l}\text { Newly planted } \\
\text { citrus trees }\end{array}$ & $\begin{array}{l}\text { Resin-coated (Meister }{ }^{\circledR} \text {; } \\
\text { Chisso-Asahi Fertilizer, } \\
\text { Tokyo) }\end{array}$ & $\begin{array}{l}\text { Yes. In a } 2 \text {-year period, EEFs applied at a } 50 \% \\
\text { rate or less performed equally well compared } \\
\text { with WSF applied at the recommended } \\
(100 \%) \text { rate. }\end{array}$ \\
\hline Boman, 1993 & Mature citrus trees & Osmocote $\AA$ & $\begin{array}{l}\text { Yes. In a } 4 \text {-year period, the EEF applied at } 15 \% \\
\text { and } 25 \% \text { rates performed equally well compared } \\
\text { with WSF applied at the recommended } \\
(100 \%) \text { rate. }\end{array}$ \\
\hline Obreza, 1993 & $\begin{array}{l}\text { Newly planted } \\
\text { citrus trees }\end{array}$ & IBDU, MU & $\begin{array}{l}\text { No. In a 4-year period, there was no interaction } \\
\text { between fertilizer source and rate with respect } \\
\text { to tree growth, fruit yield, or juice quality. }\end{array}$ \\
\hline Sartain, 1994a, 1994b & $\begin{array}{l}\text { Bermudagrass, } \\
\text { ryegrass }\end{array}$ & IBDU, PCSCU & $\begin{array}{l}\text { Single-season study. No for both turf growth } \\
\text { and visual quality. }\end{array}$ \\
\hline $\begin{array}{l}\text { Ferguson and } \\
\text { Davies, } 1995\end{array}$ & $\begin{array}{l}\text { Newly planted } \\
\text { citrus trees }\end{array}$ & PCU, IBDU, Osmocote ${ }^{\circledR}$ & $\begin{array}{l}\text { Yes. In a } 4 \text {-year period, all EEFs applied at a } \\
20 \% \text { rate performed equally well compared } \\
\text { with WSF applied at the recommended } \\
(100 \%) \text { rate. }\end{array}$ \\
\hline Sartain, 1995b & $\begin{array}{l}\text { Warm- and } \\
\text { cool-season } \\
\text { turfgrasses }\end{array}$ & $\begin{array}{l}\text { UF, } \mathrm{MU}, \mathrm{IBDU} \\
\text { coated WSF }\end{array}$ & $\begin{array}{l}\text { Single-season study. No for turf growth and } \\
\text { visual quality. }\end{array}$ \\
\hline Sartain, 1996a & Ryegrass & IBDU, coated WSF & $\begin{array}{l}\text { In a single-season study, no for turf growth, } \\
\text { yes for turf visual quality; same visual quality } \\
\text { from a half-rate of the EEF compared with a } \\
\text { full WSF rate. }\end{array}$ \\
\hline Sartain, 1996b & Bermudagrass & $\begin{array}{l}\text { IBDU, coated ammonium } \\
\text { sulfate }\end{array}$ & $\begin{array}{l}\text { In a single-season study, no for turf growth and } \\
\text { visual quality. }\end{array}$ \\
\hline $\begin{array}{l}\text { Alva and } \\
\text { Paramasivam, } 1998\end{array}$ & Mature citrus trees & PCU & $\begin{array}{l}\text { No. In a } 3 \text {-year period, there was no interaction } \\
\text { between fertilizer source and rate with } \\
\text { respect to sweet orange yield. }\end{array}$ \\
\hline Obreza et al., 1999 & $\begin{array}{l}\text { Newly planted } \\
\text { citrus trees }\end{array}$ & $\begin{array}{l}\text { Escote }{ }^{\circledR} \text { (Spectrum Brands, } \\
\text { Atlanta, GA), Meister }{ }^{\circledR}, \\
\text { Osmocote }{ }^{\circledR}, \text { Nutricote }{ }^{\circledR}, \\
\text { Prokote }{ }^{\circledR} \text { (Scotts) }\end{array}$ & $\begin{array}{l}\text { Yes. In a } 6 \text {-year period, Osmocote }{ }^{\circledR} \text { applied } \\
\text { at a } 50 \% \text { rate performed equally well compared } \\
\text { with WSF applied at the recommended } \\
(100 \%) \text { rate. }\end{array}$ \\
\hline Hutchinson et al., 2003 & Potato & PCU, PCSCU & $\begin{array}{l}\text { Yes. In a single-year study, EEFs applied at } 50 \% \\
\text { and } 75 \% \text { rates performed equally well compared } \\
\text { with WSF applied at the recommended } \\
(100 \%) \text { rate. }\end{array}$ \\
\hline Obreza and Rouse, 2006 & $\begin{array}{l}\text { Young-bearing } \\
\text { citrus trees }\end{array}$ & IBDU, MU & $\begin{array}{l}\text { No. In a } 4 \text {-year period, there was no interaction } \\
\text { between fertilizer source and rate with respect } \\
\text { to total soluble solids yield. }\end{array}$ \\
\hline
\end{tabular}

${ }^{{ }^{2} \mathrm{MU}}=$ methylene urea, $\mathrm{SCU}=$ sulfur-coated urea, $\mathrm{IBDU}=$ isobutylidene diurea, $\mathrm{PCU}=$ polymer-coated urea, $\mathrm{PCSCU}=$ polymer-coated sulfur-coated urea, $\mathrm{UF}=$ urea formaldehyde. 
no definitive answer. Of the $16 \mathrm{ex}-$ periments summarized, six showed that a lower rate of EEF performed as well or better than a higher rate of WSF, eight showed no rate advantage to EEF, and two showed mixed results depending on the measured response. Of the six "yes" answers, five involved citrus trees and one involved vegetables. Of the eight "no" answers, three involved citrus, three involved turfgrass, and two involved vegetables.

$\mathrm{N}$ leaching from field-applied EEFs is assumed to be minimal because, by design, these materials release water-soluble $\mathrm{N}$ at a slow rate. Nitrogen not released to the soil remains in an insoluble form or is protected from dissolution by a coating, therefore it cannot leach all at once. Leaching from EEFs has been measured in laboratory simulations with no plants (Table 5), measured in field lysimeters containing turfgrass (Table 6), and estimated in a central Florida citrus grove on deep sandy soil (Table 7 ). In all cases, $\mathrm{N}$ leaching from water-soluble $\mathrm{N}$ fertilizer was greater than leaching from EEFs. Nitrogen leaching from containerized plant production has also been measured (Broschat 1995; Table 8). In one experiment, plant growth substrate influenced the relative amount of fertilizer $\mathrm{N}$ that leached. Less nitrate leached from EEFs compared with WSF when plants were grown in pine bark-peat-sand media. When the media was sandy field soil, nitrate leaching did not differ between fertilizer types. Phosphorus leaching from EEFs was always significantly lower compared with WSF, regardless of potting substrate type. Plant growth was as good or better with EEFs compared with WSF.

\section{Natural organic soil amendments and fertilizers}

This grouping includes less processed materials like animal manure and biosolids that may or may not have a guaranteed nutrient analysis, plus more refined materials like fish and seaweed emulsions that are sold as commercial products with a guaranteed analysis. If an organic material is included as part of a nutrient management plan, the mineralization rate must be considered when determining the rate to apply (Treadwell et al.,

Table 5. Leaching of water-soluble and enhanced efficiency nitrogen $(\mathrm{N})$ fertilizer applied to a sandy Entisol followed by exposure to simulated rainfall events.

\begin{tabular}{llc}
\hline Study reference & \multicolumn{1}{c}{ Fertilizer } & $\begin{array}{c}\text { N leached } \\
\text { (\% of N applied })^{\mathrm{z}}\end{array}$ \\
\hline Wang and Alva, 1996 & \multicolumn{1}{c}{$100 \mathrm{a}$} \\
& Ammonium nitrate & $32 \mathrm{~b}$ \\
& Isobutylidene diurea & $12 \mathrm{c}$ \\
& Meister ${ }^{\circledR}$ plastic coated & \\
Paramasivam and Alva, 1997x & (Chisso-Asahi Fertilizer, Tokyo) & $28 \mathrm{a}$ \\
& Urea & $12 \mathrm{~b}$ \\
& Poly-S® (Scotts, Marysville, OH) & $6 \mathrm{c}$ \\
& Meister ${ }^{\circledR}$ plastic coated & $5 \mathrm{c}$ \\
\hline
\end{tabular}

${ }^{2}$ Within each study, values followed by the same letter are not significantly different from each other at $P<0.05$. ${ }^{y} 102 \mathrm{~cm}$ (40.2 inches) of simulated rainfall applied in eight events during a $29-\mathrm{d}$ period.

${ }^{\mathrm{x}} 40 \mathrm{~cm}$ (15.7 inches) of simulated rainfall applied in eight events during a $42-\mathrm{d}$ period.

Table 6. Leaching of nitrogen $(\mathrm{N})$ from water-soluble and enhanced efficiency fertilizer (EEF) sources $125 \mathrm{~d}$ after applying $\mathrm{N}$ fertilizer at a rate of $2 \mathrm{lb} / 1000 \mathrm{ft}^{2}$ $\left(97.6 \mathrm{~kg} \cdot \mathrm{ha}^{-1}\right)$ to ryegrass (J.B. Sartain, unpublished data).

\begin{tabular}{llc}
\hline Fertilizer type & \multicolumn{1}{c}{ N source } & $\begin{array}{c}\text { N leached (\% of } \\
\text { N applied })^{\mathbf{z}}\end{array}$ \\
\hline Water-soluble & Ammonium sulfate & $12.8 \mathrm{a}$ \\
Water-soluble & Urea-ammonium nitrate & $8.1 \mathrm{~b}$ \\
EEF & CoRon® (Helena Chemical, Collierville, TN) & $7.2 \mathrm{~b}$ \\
EEF & Nutralene® methylene urea (Agrium & $2.9 \mathrm{c}$ \\
& $\quad$ Advanced Technologies, Sylacauga, AL) & $2.8 \mathrm{c}$ \\
EEF & Polyon® (Agrium Advanced Technologies) & $2.8 \mathrm{c}$ \\
EEF & Sulfur-coated urea & $1.1 \mathrm{~d}$ \\
EEF & Isobutylidene diurea & $0.4 \mathrm{e}$ \\
EEF & Nitroform ${ }^{\circledR}$ ureaform (Agrium & \\
& Advanced Technologies) & \\
\hline
\end{tabular}

${ }^{2}$ Values followed by the same letter are not significantly different from each other at $P<0.05$.

Table 7. Estimated annual nitrate-nitrogen $\left(\mathrm{NO}_{3}-\mathrm{N}\right)$ leached below the root zone of a central Florida citrus grove planted on deep sandy soil and treated with three methods of $\mathrm{N}$ fertilization. Data represent the mean of a 2 -year period (Paramasivam et al., 2001). Quadratic regressions of annual $\mathrm{NO}_{3}-\mathrm{N}$ leached versus $\mathrm{N}$ rate for each fertilization method were significant at $P<0.05$.

\begin{tabular}{lccc}
\hline & Dry soluble fertilizer & Fertigation & EEF \\
\cline { 2 - 4 } $\mathbf{N}$ rate $\left(\mathbf{k g} \cdot \mathbf{h a}^{-1}\right)^{\mathbf{z}}$ & \multicolumn{4}{c}{$\left[\mathrm{NO}_{3}-\mathbf{N}\right.$ leached $\left(\mathrm{kg} \cdot \mathrm{ha}^{-1}\right.$ per $\left.\left.\mathbf{~ y r}\right)\right]$} & \\
\hline 56 & - & - & 0.8 \\
112 & 11.4 & 17.3 & 2.2 \\
168 & 12.4 & 21.3 & 5.6 \\
224 & 13.9 & 26.9 & - \\
280 & 22.0 & 32.2 & - \\
\hline
\end{tabular}

${ }^{\mathrm{z}} \mathrm{kg} \cdot \mathrm{ha}^{-1}=0.8922 \mathrm{lb} / \mathrm{acre}$

2007). Organic matter decomposes relatively quickly in Florida's warm and humid climate. For example, Hanselman et al. (2004) showed that roughly half of the $\mathrm{N}$ in biosolids and two-thirds of the $\mathrm{N}$ in poultry (layer) manure mineralized to plant-available forms during the first year after application at several Florida locations. The $\mathrm{N}$ mineralization was frontloaded for poultry manure and bio- solids (i.e., most of the $\mathrm{N}$ became plant-available in the first month after application, followed by a gradual release of the remainder during the subsequent 11 months). A similar release of $\mathrm{N}$ from seabird guano, fish powder, feather meal, and blood meal was observed by Hartz and Johnstone (2006). In their study, most of the applied $\mathrm{N}$ mineralized within 2 weeks. 
Table 8. Container-grown foliage (peace lily) plant size and relative amount of nitrate-nitrogen $\left(\mathrm{NO}_{3}-\mathrm{N}\right)$ and orthophosphate-phosphorus $\left(\mathrm{PO}_{4}-\mathrm{P}\right)$ leached 6 months after enhanced efficiency fertilizer (EEF) or water-soluble fertilizer (WSF) application to pine bark-peat-sand media or sandy field soil (Broschat, 1995).

\begin{tabular}{|c|c|c|c|c|c|c|}
\hline \multirow[b]{2}{*}{ Fertilization method } & \multicolumn{2}{|c|}{ Plant dry wt $(g)^{\mathrm{z}}$} & \multicolumn{2}{|c|}{$\begin{array}{l}\mathrm{NO}_{3}-\mathrm{N} \text { leached } \\
(\% \text { of } \mathrm{N} \text { applied })\end{array}$} & \multicolumn{2}{|c|}{$\begin{array}{l}\mathrm{PO}_{4}-\mathrm{P} \text { leached } \\
\text { (\% of } \mathrm{P} \text { applied })\end{array}$} \\
\hline & $\begin{array}{c}\text { Pine bark-peat-sand } \\
\text { media }^{\mathrm{y}}\end{array}$ & $\begin{array}{c}\text { Sandy } \\
\text { field soil }\end{array}$ & $\begin{array}{c}\text { Pine bark-peat-sand } \\
\text { media }\end{array}$ & $\begin{array}{c}\text { Sandy } \\
\text { field soil }\end{array}$ & $\begin{array}{c}\text { Pine bark-peat-sand } \\
\text { media }\end{array}$ & $\begin{array}{l}\text { Sandy } \\
\text { field soil }\end{array}$ \\
\hline Liquid WSF & $30 \mathrm{a}$ & $22 \mathrm{~b}$ & $48 \mathrm{~b}$ & $47 \mathrm{a}$ & $28 \mathrm{a}$ & $17 \mathrm{~b}$ \\
\hline Dry granular WSF & $28 \mathrm{a}$ & $18 \mathrm{c}$ & $54 \mathrm{a}$ & $46 \mathrm{a}$ & $23 \mathrm{~b}$ & $22 \mathrm{a}$ \\
\hline Lightly-coated EEF & $31 \mathrm{a}$ & $24 \mathrm{ab}$ & $29 \mathrm{~d}$ & $44 \mathrm{a}$ & $12 \mathrm{~d}$ & $11 \mathrm{c}$ \\
\hline
\end{tabular}

${ }^{\mathrm{z}} \mathrm{l} \mathrm{g}=0.0353 \mathrm{oz}$.

'Values followed by the same letter are not significantly different from each other at $P<0.05$.

\section{Fertigation}

Nutrient use efficiency can be increased by substituting fertigation for pre-plant WSF application in vegetable production. When bell pepper (Capsicum annuum) yield was used an indicator, $\mathrm{N}$ use efficiency increased as the proportion of $\mathrm{N}$ applied via fertigation increased [Table 9 (Shaw et al., 1996)]. Increased yield implies more $\mathrm{N}$ in the fruit per unit area, hence less potential leaching. Additional benefits of fertigation for vegetable production are summarized by Locascio (2005).

Fertigation frequency for vegetables can vary from daily application to one fertigation per week (Simonne and Hochmuth, 2007). No advantage to daily versus weekly fertigation has been observed with proper irrigation management. Nitrogen fertilizer application is most precise if rates are determined by crop growth and resulting nutrient demand. For example, $\mathrm{N}$ rates for tomato and bell pepper begin at $0.5 \mathrm{lb} /$ acre per day during the early part of the season and increase to $2.0 \mathrm{lb} /$ acre per day at peak demand.

Citrus trees do not appear to be sensitive to fertigation application frequency. This characteristic allows wide flexibility when developing a fertigation schedule. For example, the l-year growth response of newly planted citrus trees in Gainesville, FL, did not differ when fertigated 30,10 , or 5 times at the same total $\mathrm{N}$ rate (Willis et al., 1991). Growth observed with fertigation did not differ from that observed with dry granular fertilizer applied five times in 1 year. Fertigation frequency also was not a factor when applied to 6-year-old lysimeter-grown trees in Lake Alfred, FL [Table 10 (Syvertsen and Jifon, 2001)]. Neither

Table 9. Bell pepper marketable yield response to four preplant/fertigation nitrogen $(\mathrm{N})$ fertilizer combinations applied under plastic mulch to a sandy Ultisol (Shaw et al., 1996).

\begin{tabular}{lccc}
\hline $\begin{array}{l}\text { N applied } \\
\text { preplant (\%) }\end{array}$ & $\begin{array}{c}\text { N applied by } \\
\text { fertigation }(\%)\end{array}$ & $\begin{array}{c}\text { Total fancy } \\
\text { yield }\left(\mathbf{t} \cdot \mathbf{h a}^{-1}\right)^{\mathbf{z}}\end{array}$ & $\begin{array}{c}\text { Total marketable } \\
\text { yield }\left(\mathbf{t} \cdot \mathbf{h a}^{-\mathbf{1}}\right)\end{array}$ \\
\hline 0 & 100 & 4.2 & 9.1 \\
30 & 70 & 4.4 & 9.5 \\
70 & 30 & 3.8 & 8.3 \\
100 & 0 & 2.9 & 6.6 \\
\multicolumn{2}{c}{$\quad$ P value for treatment effect } & 0.0531 & 0.0006 \\
\hline
\end{tabular}

${ }^{2} 1 \mathrm{t}^{\mathrm{ha}}{ }^{-1}=0.4461$ ton/acre.

$\mathrm{N}$ uptake efficiency nor the relative amount of applied $\mathrm{N}$ that leached was significantly different when comparing about 80 fertigations per year with about 12 per year.

Horticultural plant response to fertigation is as good or better than the response observed with well-managed dry soluble fertilization. In either case, irrigation (and sometimes drainage) water management is critical for success. Nitrogen leaching following fertigation can be minimized if the crop is not over-irrigated. It cannot be overemphasized how important irrigation duration is when fertigating. Although fertigation is sometimes referred to as "spoon feeding," in this case, the "food" is watersoluble plant nutrients that can easily be driven beneath the plant root zone if too much water follows the fertilizer pulse (Simonne et al., 2003). It is true that fertigation prevents a large mass of nutrients from being leached in a single day (as could occur when heavy rain follows a dry fertilizer application), but leaching can still occur in smaller increments if irrigation management is poor. An interesting result of the study summarized in Table 10 was that even in a lysimeter with carefully controlled irrigation and a confined root system, about half of the $\mathrm{N}$ applied via fertigation leached past the root zone.

Table 7 shows an example that is contrary to the principle outlined above. Irrigation scheduling in the test citrus grove was optimal, yet more $\mathrm{N}$ leached in the fertigation treatment compared with dry soluble fertilizer applications. The authors of this study (Paramasivam et al., 2001) explained that more $\mathrm{N}$ leaching occurred with fertigation "purely because of unexpected prolonged irrigation or unexpected high rainfall following certain fertigation events in both years."

\section{Foliar fertilization with $\mathbf{N}$ and $\mathbf{P}$}

Citrus. The amount of plant nutrients that can be taken up through the leaves of a citrus tree is very small. However, there are special cases where foliar application of $\mathrm{N}$ and/or $P$ is justified. It must be recognized that a positive response may be due to additional effects of the materials on tree physiology beyond simple enhancement of tree nutrition.

Forms of urea are available that can be readily absorbed by citrus leaves. Foliar urea sprays applied during the winter have enhanced the number of flowers and yield of 'Valencia' sweet oranges (Albrigo, 1999). 
After cool temperatures or drought stress have occurred, applying 50 to $60 \mathrm{lb} /$ acre of urea can enhance flower bud induction and may increase fruit yield. Maximum penetration of urea into citrus leaves occurs within 12 to $24 \mathrm{~h}$ after spray application (Orbovic et al., 2001). Optimum conditions for foliar uptake include air temperature between 77 and $88{ }^{\circ} \mathrm{F}$, high relative humidity, and spray solution with a pH between 7 and 8 to prevent urea breakdown. Under favorable environmental conditions, roughly half of foliar-applied urea penetrates the leaves, while most of the other half is lost through volatilization. The rate of foliar-applied $\mathrm{N}$ should be considered as part of the total annual $\mathrm{N}$ rate applied to the grove. For example, a foliar spray of $50 \mathrm{lb} /$ acre of urea applies $23 \mathrm{lb} /$ acre of $\mathrm{N}$. If the fertilization plan calls for a total of $180 \mathrm{lb} /$ acre per year of $\mathrm{N}$, only $157 \mathrm{lb} / \mathrm{acre}$ should be included in the soil-applied fertilizer program. In Florida citrus production areas where groundwater nitrate contamination exists or is seen as a potential problem, urea sprays should be evaluated to provide a portion of the tree $\mathrm{N}$ requirements, especially during the summer months when leaching potential is the greatest.

Citrus leaves are extremely impervious to phosphate $\left(\mathrm{PO}_{4}{ }^{3-}\right)$ (Lovatt and Mikkelson, 2006). Conversely, phosphite $\left(\mathrm{PO}_{3}^{3-}\right)$ is more readily absorbed into plant tissue, and once inside the plant, it remains stable. Phosphite does not readily convert to phosphate in the plant, therefore the nutritional value of absorbed $\mathrm{PO}_{3}{ }^{3-}$ is uncertain. However, phosphite is officially recognized by FDACS as a source of $\mathrm{P}$ for crops. In Florida, a prebloom foliar application of $2.6 \mathrm{qt} /$ acre of $28 \% \mathrm{P}_{2} \mathrm{O}_{5}$ as potassium phosphate $\left(\mathrm{K}_{3} \mathrm{PO}_{3}\right)$ to 'Valencia' sweet oranges significantly increased flower number, fruit yield, and total soluble solids yield compared with an untreated control (Albrigo, 1999). These results suggest that the effect of phosphite was not due to the molecule's fungicidal attributes, but to other growth-stimulating properties.

OTHER HORTICULTURAL CROPS. Foliar applications of $\mathrm{N}$ and $\mathrm{P}$ are not recommended for vegetable production because leaves cannot absorb sufficient quantities to correct a deficiency, and leaf burn is likely if this is attempted (Simonne and Hochmuth,
2007). This principle also applies to ornamental plants and turfgrass.

\section{Example cost comparisons of EEF versus WSF programs}

Citrus. Although coated EEFs performed very well in a 6-year trial comparing them with a standard WSF program (1991-96), they would not have been economically feasible for commercial production. The EEF materials evaluated would have cost three to four times as much to use as WSF, even when the lower application cost was factored in (Obreza et al., 1999; Table 11). Extra yield obtained by using EEF did not nearly make up for the higher fertilizer cost.

Vegetables. A potato production study (Simonne and Hutchinson, 2005) determined that the cost of a water-soluble $\mathrm{N}$ fertilization program in most years would fall between $\$ 72 /$ ha and $\$ 158 /$ ha. Estimated EEF program cost would be about $\$ 20 /$ ha to $\$ 195 /$ ha more than the most expensive soluble $\mathrm{N}$ cost. This extra cost could be offset by reduced application cost and/or providing costshare for the use of EEF.

Table 10. Influence of the number of fertigations applied to 6-year-old sweet orange trees growing in lysimeter tanks on the relative amount of nitrogen $(\mathrm{N})$ leached and on $\mathrm{N}$ use efficiency (Syvertsen and Jifon, 2001).

\begin{tabular}{|c|c|c|c|c|}
\hline Yr & $\begin{array}{c}\text { Fertigation } \\
\text { treatment }\end{array}$ & $\begin{array}{c}\text { Fertigations } \\
(\text { no./yr })\end{array}$ & $\begin{array}{l}\text { Applied N } \\
\text { that leached (\%) }\end{array}$ & $\begin{array}{c}\mathrm{N} \text { use } \\
\text { efficiency }^{\mathrm{z}}\end{array}$ \\
\hline \multirow[t]{3}{*}{1999} & With every irrigation & 76 & 51 & 30 \\
\hline & Weekly & 36 & 58 & 27 \\
\hline & Monthly & 11 & 56 & 24 \\
\hline \multirow[t]{3}{*}{2000} & With every irrigation & 81 & 46 & 42 \\
\hline & Weekly & 38 & 62 & 28 \\
\hline & Monthly & 14 & 53 & 35 \\
\hline
\end{tabular}

${ }^{z}$ (Amount of $\mathrm{N}$ taken up by the citrus trees divided by the amount of $\mathrm{N}$ applied $) \times 100$.

Table 11. Cost of six fertilizer programs (five enhanced efficiency fertilizers and one water-soluble fertilizer) applied to young 'Valencia' sweet orange trees from 1991 through 1996 compared with cumulative lb soluble solids yield and gross monetary return (Obreza et al., 1999).

\begin{tabular}{|c|c|c|c|}
\hline Fertilizer & $\begin{array}{c}6-y r \\
\text { fertilization } \\
\text { cost }(\$ / \text { tree })\end{array}$ & $\begin{array}{l}\text { Cumulative yield } \\
\text { [total soluble } \\
\text { solids }(\mathrm{lb} / \text { tree })]^{\mathrm{z}}\end{array}$ & $\begin{array}{c}\text { Gross } \\
\text { return } \\
(\$ / \text { tree }) \\
\end{array}$ \\
\hline Prokote ${ }^{\circledR}$ (Scotts, Marysville, OH) & 15.49 & 27.7 & 28.90 \\
\hline Sierra ${ }^{\circledR}$ (Scotts) & 19.20 & 27.0 & 28.25 \\
\hline Nutricote ${ }^{\circledR}$ (Florikan, Sarasota, FL) & 19.85 & 26.5 & 27.47 \\
\hline Meister ${ }^{\circledR}$ (Chisso-Asahi Fertilizer, Tokyo) & 15.81 & 25.8 & 26.41 \\
\hline Escote ${ }^{\circledR}$ (Spectrum Brands, Atlanta, GA) & 14.90 & 24.9 & 25.98 \\
\hline Water-soluble & 5.06 & 24.2 & 25.40 \\
\hline
\end{tabular}

${ }^{\mathrm{z}} \mathrm{llb}=0.4536 \mathrm{~kg}$.

\section{How irrigation affects fertilizer}

Irrigation effects on fertilizer NUE for vegetable production were and Locascio (2005), and for citrus production by Obreza and Morgan 08 ). Fertilizer use efficiency of conwion improved by changing the irriga(Yeager and Henley, 2004). One change involved the conversion of overhead irrigation to microirrigation or other change involved the use of EEFs Polyon ] with During a 4-year period, the growth index of peace lily (Spathiphyllum spp.) was about the same regardless of EEF source. However, the nitrate-N concentration in the groundwater $4 \mathrm{ft}$ below the ground surface of the shadeuse decreased as a result of EEF use $2)$. In another study involving cortuction of Osmocote ${ }^{\circledR}$-fertilized sweet viburnum, excessive irrigation (double the required summarized by Hochmuth (2003) capillary mat/wick irrigation. The 


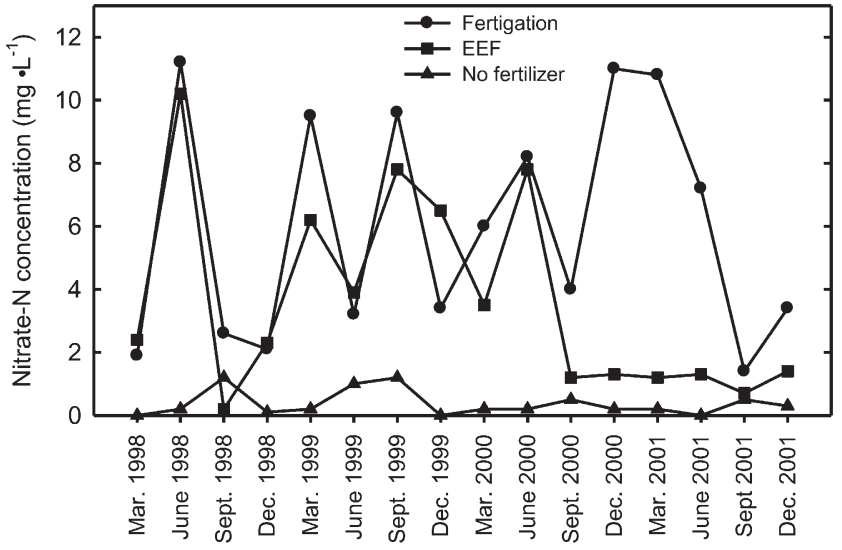

Fig. 2. Effect of nitrogen (N) fertilizer type and application method on groundwater nitrate- $\mathrm{N}$ concentration beneath ornamental plant production during a 4-year period (Yeager and Henley, 2004); EEF = enhanced efficiency fertilizer, $1 \mathrm{mg} \cdot \mathrm{L}^{-1}=1 \mathrm{ppm}$.

rate) decreased plant growth, increased runoff volume from the nursery, increased $\mathrm{N}$ loss in runoff by $21 \%$ to $34 \%$, and increased $\mathrm{P}$ loss in runoff by $28 \%$ to $38 \%$ (Million et al., 2007b).

\section{Future research needs}

Despite numerous improvements in fertilizer use efficiency that have occurred during the past several decades, further advancement is possible if research is undertaken on the following aspects of fertilizer use: 1) develop a short-term procedure to verify the nutrient release period claimed on EEF labels, 2) evaluate nutrient leaching characteristics of EEF materials applied in the field and greenhouse, 3 ) conduct an economic study of EEF use that determines the value of the environmental benefit, 4) improve irrigation scheduling techniques, and 5) develop new technology for precision nutrient application.

\section{Conclusion}

The efficiency of WSF application to Florida's horticultural crops has been enhanced by using appropriate rates, sources, application timing, and placement. Producers who implement contemporary BMPs are improving NUE to a greater extent due to the synergistic effect of commodity-oriented nutrient management practices joined in a holistic program. The next steps for producers to take include greater use of EEFs, wider adoption of fertigation, application of foliar fertilizers where appropriate, and more precise irrigation scheduling. Enhanced efficiency fertilizers hold great promise to improve NUE even more, but additional research on characterization, plant response, environmental effects, and economics is needed before EEF use can be established as a BMP.

\section{Literature cited}

Albrigo, L.G. 1999. Effects of foliar applications of urea or Nutriphite on flowering and yields of Valencia orange trees. Proc. Florida State Hort. Soc. 112:1-4.

Alva, A.K. and D.P.H. Tucker. 1993. Evaluation of a resin-coated nitrogen fertilizer for young citrus trees on a deep sand. Proc. Florida State Hort. Soc. 106:4-8.

Alva, A.K. and S. Paramasivam. 1998. Nitrogen management for high yield and quality of citrus in sandy soils. Soil Sci.

Boman, B.J. 1993. A comparison of controlled-release to conventional fertilizer on mature 'Marsh' grapefruit. Proc. Florida State Hort. Soc. 106:1-4.

Broschat, T.K. 1995. Nitrate, phosphate, and potassium leaching from containergrown plants fertilized by several methods. HortScience 30:74-77.

Broschat, T.K. 2005. Rates of ammonium-nitrogen, nitrate-nitrogen, phosphorus, and potassium from two controlled-release fertilizers under different substrate environments. HortTechnology 15:332-335.

Csizinszky, A.A., C.D. Stanley, and G.A. Clark. 1993. Evaluation of controlledrelease urea for fresh market tomato. Proc. Florida State Hort. Soc. 106:183-187.

Ferguson, J.J. and F.S. Davies. 1995. Fertilization of young citrus trees with Soc. Amer. J. 62:1335-1342. controlled-release fertilizers. Proc. Florida State. Hort. Soc. 108:156-160

Florida Department of Agriculture and Consumer Services. 2000. Water quality/ quantity BMPs for Indian River area citrus groves. 8 July 2009. <http://www.floridaag waterpolicy.com/PDF/Bmps/Bmp_ Indian RiverCitrus2000.pdf $>$.

Florida Department of Agriculture and Consumer Services. 2002. Nitrogen best management practices (BMPs) for Florida ridge citrus. 8 July 2009. <http://www. floridaagwaterpolicy.com/PDF/Bmps/ Bmp_RidgeCitrus2002.pdf $>$.

Florida Department of Agriculture and Consumer Services. 2004. Best management practices for citrus groves in the Peace River and Manasota Basins. 8 July 2009. <http://www.floridaagwaterpolicy. com/PDF/Bmps/Bmp_PeaceRiverCitrus 2004.pdf>.

Florida Department of Agriculture and Consumer Services. 2005. Water quality/quantity best management practices for Florida vegetable and agronomic crops. 8 July 2009. <http://www.florida agwaterpolicy.com / PDF / Bmps / Bmp_VeggieAgroCrops2005.pdf>.

Florida Department of Agriculture and Consumer Services. 2006. Best management practices for Gulf citrus. Publ. No. 5M-7.005.03.06. 8 July 2009. <http:// www.floridaagwaterpolicy.com/PDF/ Bmps/Bmp_GulfCitrus2005.pdf $>$.

Florida Department of Agriculture and Consumer Services. 2007a. Water quality/quantity best management practices for Florida sod. Publ. No. P 01330. 8 July 2009. <http://www.floridaagwaterpolicy. com/PDF/Bmps/Bmp_FloridaSod2008. pdfs.

Florida Department of Agriculture and Consumer Services. 2007b. Water quality/ quantity best management practices for Florida container nurseries. Publ. No. P 01267. 8 July 2009. <http://www.floridaagwaterpolicy. $\mathrm{com} / \mathrm{PDF} / \mathrm{Bmps} / \mathrm{Bmp}$ FloridaContainer Nurseries2007.pdf $>$.

Graetz, D.A., A.B. Bottcher, S.J. Locascio, and K.L. Campbell. 1987. Tomato yield and nitrogen recovery as influenced by irrigation method, nitrogen source and mulch. HortScience 22:27-29.

Hall, B. 2006. Enhanced efficiency fertilizers: Labeling, regulation, and monitoring. 23 Apr. 2009. <http://www.aapfco.org/ AACO $\% 202006 /$ AAPFCO $\% 20$ SR $\% 20$ Reg\% 2006.ppt>.

Hanselman, T.A., D.A. Graetz, and T.A. Obreza. 2004. A comparison of in situ methods for measuring net nitrogen mineralization rates of organic soil amendments. J. Environ. Qual. 33:1098-1105. 
Hartz, T.K. and P.R. Johnstone. 2006. Nitrogen availability from high-nitrogen containing-organic fertilizers. HortTechnology 16:39-42.

Hochmuth, G.J. 2003. Progress in mineral nutrition and nutrient management for vegetable crops in the last 25 years. HortScience 38:999-1003.

Hutchinson, C., E. Simonne, P. Solano, J. Meldrum, and P. Livingston-Way. 2003. Testing of controlled-release fertilizer programs for seep irrigated irish potato production. J. Plant Nutr. 26:1709-1723.

Locascio, S.J. 2005. Management of irrigation for vegetables: Past, present, and future. HortTechnology 15:482-485.

Locascio, S.J. and M.R. Alligood. 1992. Nitrogen and potassium source and $\mathrm{N}$ rate for drip-irrigated pepper. Proc. Florida State Hort. Soc. 105:323-325.

Lovatt, C.J. and R.L. Mikkelson. 2006. Phosphite fertilizers: What are they? Can you use them? What can they do? Better Crops Plant Food 90(4):11-13.

Medina, L.C., T.A. Obreza, J.B. Sartain, and R.E. Rouse. 2008. Nitrogen release patterns of a mixed controlled-release fertilizer and its components. HortTechnology 18:475-480.

Million, J., T. Yeager, and J. Albano. 2007a. Effects of container spacing practice and fertilizer placement on runoff from overhead-irrigated sweet viburnum. J. Environ. Hort. 25:61-72.

Million, J., T. Yeager, and J. Albano. 2007b. Consequences of excessive overhead irrigation on runoff during container production of sweet viburnum. J. Environ. Hort. 25:117-125.

Obreza, T.A. 1993. Program fertilization for establishment of orange trees. J. Prod. Agr. 6:546-552.

Obreza T.A. and K.T. Morgan (eds.). 2008. Nutrition of Florida citrus trees, 2nd ed. Univ. Florida, Inst. Food Agr. Sci., Soil Water Sci. Dept. SL253. 23 Apr. 2009. <http://edis.ifas.ufl.edu/SS478>.

Obreza, T.A. and R.E. Rouse. 2006. Long-term response of 'Hamlin' orange trees to controlled-release nitrogen fertilizers. HortScience 41:423-426.

Obreza, T.A., R.E. Rouse, and J.B. Sherrod. 1999. Economics of controlled-release fertilizer use on young citrus trees. J. Prod. Agr. 12:69-73.

Olson, S.M. and E. Simonne, (eds.). 2007. Vegetable production guide for Florida. Univ., Florida, Inst. Food Agr. Sci., Hort Sci. Dept. HS710. 23 Apr. 2009. <http://edis.ifas.ufl.edu/features/ handbooks/vegetableguide.html>.
Orbovic, V., D. Achor, P. Petracek, and J.P. Syvertsen. 2001. Air temperature, humidity, and leaf age affect penetration of urea through grapefruit leaf cuticles. J. Amer. Soc. Hort. Sci. 126:44-50.

Paramasivam, S., A.K. Alva, A. Fares, and K.S. Sajwan. 2001. Estimation of nitrate leaching in an Entisol under optimum citrus production. Soil Sci. Soc. Amer. J. 65:914-921.

Paramasivam, S. and A.K. Alva. 1997. Leaching of nitrogen forms from controlled-release nitrogen fertilizers. Commun. Soil Sci. Plant Anal. 28:1663-1674.

Saha, S.K., L.E. Trenholm, and J.B. Unruh. 2007. Effect of fertilizer source on nitrate leaching and st. augustinegrass turfgrass quality. HortScience 42:14781481 .

Sartain, J.B. 1992. Relative nitrogen leaching losses from selected slow-release nitrogen sources, p. 131-136. In: T.E. Freeman (ed.). Turfgrass research in Florida. Univ. Florida, Inst. Food Agr. Sci., Gainesville.

Sartain, J.B. 1993. Comparative growth rate and quality response of bermudagrass and ryegrass to various sources of slowrelease $\mathrm{N}$ fertilizer, p. 77-81. In: J.L. Cisar and J.J. Haydu (eds.). Turfgrass research in Florida. Univ. Florida, Inst. Food Agr. Sci., Gainesville.

Sartain, J.B. 1994a. Bermudagrass growth and quality response to poly-S materials, p. 51-63. In: A.E. Dudeck (ed.). Turfgrass research in Florida. Univ. Florida, Inst. Food Agr. Sci., Gainesville.

Sartain, J.B. 1994b. Controlled-release nitrogen sources for cool and warm season grasses, p. 95-103. In: A.E. Dudeck (ed.). Turfgrass research in Florida. Univ. Florida, Inst. Food Agr. Sci., Gainesville.

Sartain, J.B. 1994c. Effects of Multicote materials on ryegrass growth and quality, p. 110-115. In: A.E. Dudeck (ed.). Turfgrass research in Florida. Univ. Florida, Inst. Food Agr. Sci., Gainesville.

Sartain, J.B. 1995a. St. Augustinegrass growth response to controlled-release blends, p. 57-70. In: J.L. Cisar (ed.). Turfgrass research in Florida. Univ. Florida, Inst. Food Agr. Sci., Gainesville.

Sartain, J.B. 1995b. Warm and cool season turfgrass response to controlled-release nitrogen, p. 165-174. In: J.L. Cisar (ed.). Turfgrass research in Florida. Univ. Florida, Inst. Food Agr. Sci., Gainesville.

Sartain, J.B. 1996a. Response of ryegrass to controlled-release nitrogen sources, $\mathrm{p}$. 190-192. In: J.L. Cisar (ed.). Turfgrass research in Florida. Univ. Florida, Inst. Food Agr. Sci., Gainesville.
Sartain, J.B. 1996b. Response of bermudagrass to controlled-release nitrogen sources, p. 212-214. In: J.L. Cisar (ed.). Turfgrass research in Florida. Univ. Florida, Inst. Food Agr. Sci., Gainesville.

Sartain, J.B. 2007. General recommendations for fertilization of turfgrasses on Florida soils. Univ. Florida, Inst. Food Agr. Sci., Coop. Ext. Serv. SL2 1. 23 Apr. 2009. <http://edis.ifas.ufl.edu/LH014>.

Sartain, J.B. and J.K. Kruse. 2001. Selected fertilizers used in turfgrass fertilization. Univ. Florida, Inst. Food Agr. Sci., Soil Water Sci. Dept. Circ. 1262. 23 Apr. 2009. <http://edis.ifas.ufl.edu/SS318>.

Schwab, G.J. and L.W. Murdock. 2005. Nitrogen transformation inhibitors and controlled-release urea. Univ. Kentucky Coop. Ext. Serv. AGR185.

Shaw, N.L., G.J. Hochmuth, and E.A. Hanlon. 1996. N fertilization management for drip-irrigated bell pepper (Capsicum annumm L.). Proc. Florida State Hort. Soc. 109:136-141.

Simonne, E. and C.M. Hutchinson. 2005. Controlled-release fertilizers for vegetable production in the era of best management practices: Teaching new tricks to an old dog. HortTechnology 15:36-46.

Simonne, E.H. and G.J. Hochmuth. 2007. Soil and fertilizer management for vegetable production in Florida. Univ. Florida, Inst. Food Agr. Sci., Hort. Sci. Dept. HS711. 23 Apr. 2009. <http:// edis.ifas.ufl.edu/CV101>.

Simonne, E.H., D.W. Studstill, R.C. Hochmuth, G. McAvoy, M.D. Dukes, and S. Olson. 2003. Visualization of water movement in mulched beds with injections of dye with drip irrigation. Proc. Florida State Hort. Soc. 116:88-91.

Syvertsen, J.P. and J.L. Jifon. 2001. Frequent fertigation does not affect citrus tree growth, fruit yield, nitrogen uptake, and leaching losses. Proc. Florida State Hort. Soc. 114:88-93

Thomas, M. (ed.). 2007. Best management practices for the enhancement of environmental quality on Florida golf courses. 8 July 2009. <http://www.dep.state.fl. us/water/nonpoint/docs/nonpoint/ glfbmp07.pdf>.

Thomas, M. (ed.). 2008. Florida friendly best management practices for protection of water resources by the green industries. 8 July 2009. <http://www.dep.state.flus/water/nonpoint/docs/nonpoint/ grn-ind-bmp-en-12-2008.pdf>.

Treadwell, D.D., G.J. Hochmuth, R.C. Hochmuth, E.H. Simonne, L.L. Davis, W.L. Laughlin, Y. Li, T. Olczyk, R.K. Sprenkel, and L.S. Osborne. 2007. 
Nutrient management in organic greenhouse herb production: Where are we now? HortTechnology 17:461-466.

Varshovi, A.A. and J.B. Sartain. 1993. Growth, N uptake, and leaching characteristics of polymer-coated urea and ammonium sulfate applied to bermudagrass, p. 5967. In: J.L. Cisar and J.J. Haydu (eds.). Turfgrass research in Florida. Univ. Florida, Inst. Food Agr. Sci., Gainesville.

Varshovi, A.A. and J.B. Sartain. 1996a. Nitrogen uptake of Tifway bermudagrass in response to polymer-coated ammonium sulfate, p. 149-152. In: J.L. Cisar (ed.). Turfgrass research in Florida. Univ. Florida, Inst. Food Agr. Sci., Gainesville.
Varshovi, A.A. and J.B. Sartain. 1996b. Comparative growth of Tifgreen bermudagrass in response to golf greens grade polymer-coated ammonium sulfate and urea, p. 153-159. In: J.L. Cisar (ed.). Turfgrass research in Florida. Univ. Florida, Inst. Food Agr. Sci., Gainesville.

Varshovi, A.A. and J.B. Sartain. 1996c. Nitrogen uptake of Tifgreen bermudagrass in response to golf greens grade polymer-coated ammonium sulfate, $\mathrm{p}$. 171-174. In: J.L. Cisar (ed.). Turfgrass research in Florida. Univ. Florida, Inst. Food Agr. Sci., Gainesville.

Wang, F.L. and A.K. Alva. 1996. Leaching of nitrogen from slow-release urea sources in sandy soils. Soil Sci. Soc. Amer. J. 60:1454-1458.

Willis, L.E., F.S. Davies, and D.A. Graetz. 1991. Fertigation and growth of young 'Hamlin' orange trees in Florida. HortScience 26:106-109.

Yeager, T.H. and R.W. Henley. 2004. Irrigation and fertilization for minimal environmental impact. Acta Hort. 638: 233-240.

Zekri, M. and R.C.J. Koo. 1992. Use of controlled-release fertilizers for young citrus trees. Scientia Hort. 49:233-241. 